\title{
Three-Dimensional Reconstruction of Halamphora coffeaeformis Frustule from Scanning Electron Micrographs
}

Francisco Ezequiel Navarro ${ }^{1,2 *}$, Cecilia Angelines Popovich ${ }^{1,3}$, Miguel Sánchez ${ }^{4}$, Ignacio Costilla ${ }^{5}$, Cecilia Gutierrez Ayesta ${ }^{6}$, Patricia Leonardi ${ }^{1}$

1-Centro de Recursos Naturales Renovables de la Zona Semiárida (CERZOS) (CONICETUniversidad Nacional del Sur [UNS]), Camino de La Carrindanga Km 7, B8000CPB Bahía Blanca. Argentina. Departamento de Biología, Bioquímica y Farmacia. UNS. San Juan 670, B8000CPB Bahía Blanca. Argentina.

2-Comisión de Investigaciones Científicas (CIC). Calle 526 entre 10 y 11, (1900) La Plata. Argentina.

3-Centro de Emprendedorismo y Desarrollo Territorial Sostenible (CEDETS) (CIC-UPSO), Ciudad de Cali, B8000CPB Bahía Blanca. Argentina

4-Instituto de Física del Sur (IFISUR), Departamento de Física, UNS, CONICET, Av. L.N. Alem 1253, B8000CPB - Bahía Blanca, Argentina.

5- Instituto de Física del Sur (IFISUR), UNS, CONICET, Av. L.N. Alem 1253, B8000CPB - Bahía

Blanca, Argentina

6-Servicio de Microscopía Electrónica. UAT-CCT-CONICET, Camino de La Carrindanga Km 7, B8000CPB Bahía Blanca. Argentina. Departamento de Biología, Bioquímica y Farmacia. UNS. San Juan 670, B8000CPB Bahía Blanca. Argentina

*fenavarro@cerzos-conicet.gob.ar

The diatom Halamphora coffeaeformis represents an alternative feedstock of oils for the biodiesel production [1]. In addition, its siliceous cell wall (named frustule) presents possible industrial applications that have not been reported in the literature yet. Thus, the main objective of this study was to perform a three-dimensional reconstruction of $H$. coffeaeformis' frustule from scanning electron micrographs, in order to have a study model. For this, the biomass of the species growing in a photobioreactor was harvested and treated as follows: a) some samples were dehydrated and subjected to a critical point; and b) other samples were treated with $\mathrm{H}_{2} \mathrm{O}_{2}$ in order to analyse the frustule's ornamental pattern. All samples were metallized with gold, using an Argon plasma metal evaporator (Pelco model3) and they were observed with a LEO Scanning Electron Microscope, model EVO 40 XVP 2004. The frustules were elliptical to lanceolate with protracted ends. Valves presented convex dorsal margin and straight ventral margin. Dorsal striae were biseriate and radiate; ventral striae were short, uniseriate, radiate at the center and convergent at the ends of the valves. The raphe was straight and close to the ventral margin (Fig. 1A). The micrographs were analysed and separated into layers with the Adobe Photoshop CS6 software. The layers were vectorised with the Inkscape software and loaded and assembled in the Tinkercad software (Fig. 1B). The final aspects of the digital model were moulded on the page https://stephaneginier.com/sculptgl/. Finally, 3D printing was done with a CoLiDoTM 3.0 L printer, obtaining a three-dimensional replica representative of the H. coffeaeformis ${ }^{\prime}$ morphology (Fig. 2). This replica will serve as a model for studies of its frustules related to nanotechnology and /or catalyst support applications [2]. 
References:

[1] L.A. Martín et al., Renew. Energy 118 (2018), p. 984.

[2] This research was supported by grants from Agencia Nacional de Promoción Científica y Tecnológica PICT 2015-0800; Consejo Nacional de Investigaciones Científicas y Técnicas de la República Argentina (CONICET, PIP 112-2015 01-00510); Universidad Nacional del Sur (PGI 24/B246) to PIL and Ideas-Proyecto de Investigación en Temas Prioritarios y de Impacto para la Provincia de Buenos Aires (CIC-1480/18) to CAP. PIL, MS and IC are Research Members of CONICET, CAP is a Research Member of CIC and FEN is a Doctoral Fellowship of CIC.
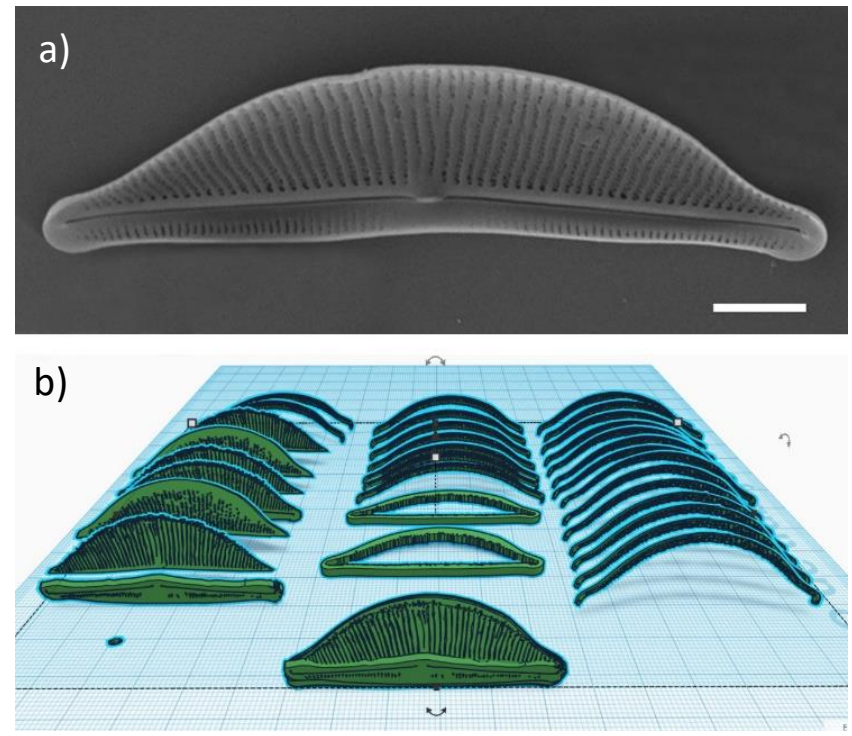

Figure 1. Halamphora coffeaeformis. a) Internal valve view of the frustule with dorsal and ventral striae separated by the raphe. Scale bar $=3 \mu \mathrm{m}$. b) Vectorised and assembled images in the Tinkercad software.
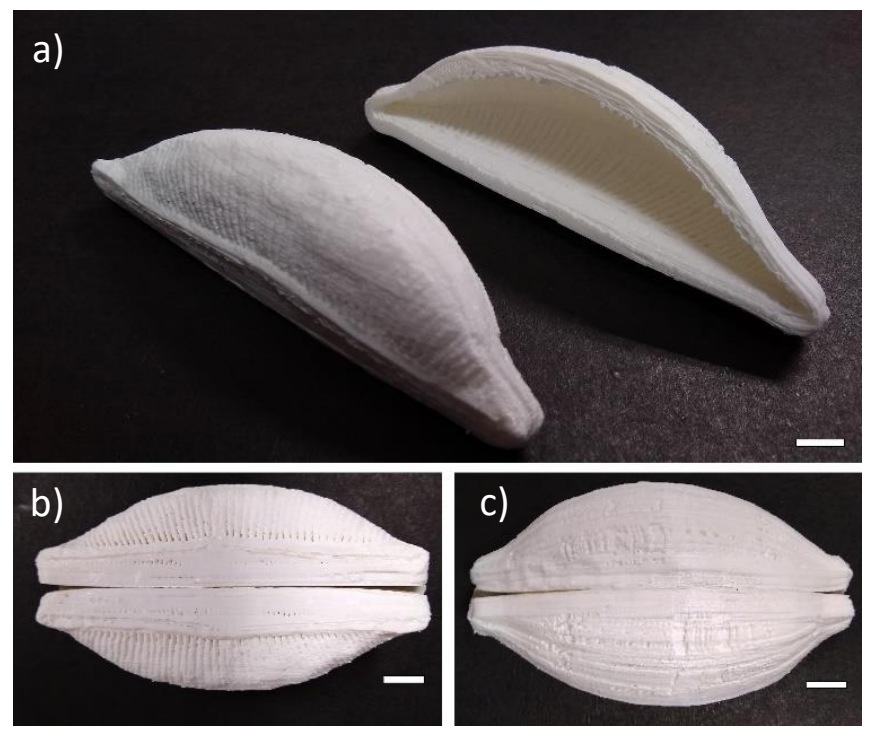

Figure 2. Representative three-dimensional replica of the H. coffeaeformis frustule. a) Internal and external valve view. b) Ventral girdle view. c) Dorsal girdle view. Scale bar $=1 \mathrm{~cm}$. 